\title{
SMALL-SCALE MANJUBA FISHERY AROUND CARDOSO ISLAND STATE PARK, SP, BRAZIL
}

\author{
CARDOSO, T. A. and NORDI, N. \\ Laboratório de Ecologia Humana e Etnoecologia, Departamento de Hidrobiologia, Universidade Federal de São Carlos, \\ Via Washington Luis, Km 235, C. P. 676, CEP 13565-905, São Carlos, SP, Brazil \\ Correspondence to: Thaís Almeida Cardoso, Laboratório de Ecologia Humana e Etnoecologia, \\ Departamento de Hidrobiologia, Universidade Federal de São Carlos, Via Washington Luis, Km 235, \\ C. P. 676, CEP 13565-905, São Carlos, SP, Brazil, e-mail: nivaldo@power.ufscar.br \\ Received July 14, 2004 - Accepted May 24, 2005 - Distributed November 1, 2006
}

(With 2 figures)

\begin{abstract}
This work was carried out in the Enseada da Baleia and Vila Rápida communities. Data was provided by the Co-Management Committee of the Cardoso Island State Park (PEIC) on manjuba fishery management, technique and strategies used by the fishermen, as well as locally accumulated knowledge. Based on the results, social, ecological, and economic aspects of this type of fishing were analyzed. The importance of the accumulated knowledge and experience of this community, as well as the limitations imposed by local fishing gear, was concluded to be essential in conserving manjuba fishery conditions in the area. Industrial fishing, relevant state legislation, and market conditions were found to be the main obstacles to local fishery. Various proposals are suggested for manjuba fishery management, with emphasis on the need for fishing community participation in whatever measures are ultimately implemented.
\end{abstract}

Keywords: manjuba fishing, iriko, small-scale fishery, human ecology and ethnoecology.

\section{RESUMO}

\section{A pesca artesanal da manjuba no parque estadual da Ilha do Cardoso, SP, Brasil}

O trabalho foi desenvolvido nas comunidades Enseada da Baleia e Vila Rápida (PEIC), com a finalidade de reunir subsídios para o manejo participativo da pesca da manjuba. Foram obtidos dados da técnica e estratégias utilizadas na pesca da manjuba, sobre conhecimento local dos pescadores estudados, além de analisados os aspectos sociais, ecológicos e econômicos envolvidos nesse tipo de pesca. Foi observado que os conhecimentos e práticas dos pescadores, associados à limitação dos apetrechos de pesca, são importantes para a execução de uma pesca mais seletiva e para a conservação do recurso. Verificou-se que a pesca industrial, a fiscalização e o mercado restrito são os principais fatores externos que interferem diretamente na atividade pesqueira estudada. A partir da análise do contexto em que a pesca da manjuba está inserida, foram sugeridas propostas para o manejo da atividade, ressaltando-se a necessidade de sua realização de forma participativa, juntamente com as comunidades usuárias do recurso.

Palavras-chave: pesca da manjuba, iriko, pesca artesanal, ecologia humana e etnoecologia.

\section{INTRODUCTION}

For approximately the past 70 years smallscale manjuba fishing, also called iriko fishing, has been a common caiçara ${ }^{1}$ activity by estuary

${ }^{1}$ Caiçara cultural identity originated in a mixture of indigenous inhabitant, Portuguese colonizer and, to a lesser degree, African slave contributions (Diegues, 2001). Currently, this term designatse the coastal inhabitants of Paraná, São Paulo, and Rio de Janeiro states (Diegues, 1988). fishermen, from the south of Cardoso Island to the Paranaguá Bay on the northern coast of Paraná State.

The present study of this type of fishery was motivated by current legislative restrictions, which threaten the livelihood of local communities.

One of these restrictions prohibits the use of the filó net whose fine mesh can cause mortality in juveniles of other species inhabiting estuarine 
areas (IBAMA regulation $\mathrm{n}^{\circ}$ 135/94 - N, 1994, article 1).

Small-scale manjuba fishing in Paraná State has been cited by some authors (Figueiredo \& Menezes, 1978; Ésper, 1980; Pinheiro et al., 1994; Melo, 1996), who studied the taxonomy and the biology of locally fished manjuba, whose species has not yet been determined. Along the Paraná coast, Andriguetto-Filho (1999) studied the fishery systems and their dynamics, including that of iriko fishing, which occurs in the Laranjeiras and Pinheiros bays. Mourão (1971) found that manjuba fishery is common around Cardoso Island (São Paulo State), and Sales (1988) indicated this type of fishery as one of the factors that reduce fish populations in the Iguape-Cananéia lagoon region.

This work was done in response to a request from the Enseada da Baleia and Vila Rápida communities, which partially comprise the Co-Management Committee of the Cardoso Island State Park (PEIC). This committee shares responsibility with government agencies in managing park resources, thereby exemplifying co-management (Seixas \& Berkes, 2003). Area resource management relies on both local and scientific knowledge about fishes and fisheries, and respects state fishery legislation. Interacting Fishermen's interactions are governed by commonly accepted norms.

This study intends to show how this system functions from the economic, ecological, and social viewpoint on Cardoso Island among manjuba fishermen. Using an ethnoecological approach proposed by Toledo (1992), the main source of community livelihood, as well as local accumulated knowledge about fishes and their environment were studied. Integration between local informal and formal ecological knowledge was also studied, as suggested by Marques (1995), to form a basis for planning co-management in the Cardoso Island State Park.

\section{MATERIAL AND METHODS}

\section{Area of study}

Cardoso Island is part of Cananéia, a city located at the most southerly point of São Paulo State's coast (lat. $25^{\circ} 05^{\prime} \mathrm{S}-25^{\circ} 15^{\prime} \mathrm{S}$ and long. $\left.47^{\circ} 53^{\prime}-48^{\circ} 06^{\prime} \mathrm{W}\right)$. The approximately 22,500 hectare island faces Trapandé Bay and the Ararapira
Channel on the north and northeast, the Atlantic Ocean on the east, and the mouth of the Ararapira Channel on the east (Fig. 1). The Iguape, Cananéia, and Paranaguá Lagoon/Estuary complex, which is mainly drained by the Ribeira do Iguape basin, is one of the largest sea-species nurseries in of the South Atlantic (PEIC Management Plan, 2001).

The present work was carried out in the Enseada da Baleia and Vila Rápida villages (Fig. 1), which are located on the southern coast of Cardoso Island on a projection of land facing the Atlantic Ocean on the east and the estuarine channel on the west, and approximately $1 \mathrm{~km}$ apart. The total population numbers 56, of which 27 inhabit Vila Rápida while the remaining 29 live in Enseada da Baleia.

\section{Methodological procedures}

In order to carry out the present work, nine field trips of one week each were carried out between July 2001-August 2003. During the entire study all manjuba fishermen (12) of the two communities and two local manjuba buyers were part of the research.

This work included non-structured (Mello, 1995) and semi-structured interviews (Viertler, 2002), and informal colloquies directed towards fishery technique and strategies and the social, economic, and ecological context in which they were used. Life history was the anthropological tool (Viertler, 2002) chosen to obtain descriptions of manjuba fishery from the oldest fishermen of the two communities. With previous permission of those interviewed, most of the conversations were recorded and immediately transcribed either in the field, or later on in the laboratory. Information yielded was analyzed in order to obtain the most commonly cited features in both communities.

We used the direct observation technique (Chizzotti, 2000) for studying manjuba fishery, and the northern- and southern-most points of the estuarine channel area used by the manjuba fishermen were identified through the Global Positioning System (GPS). Decoding of the fishermen's ecological knowledge was done using componential analysis (Marques, 1995). A regional map of the migratory routes and habits of the regional manjuba species region was used to check information gathered from the fishermen. Manjuba samples caught by the fishermen were 


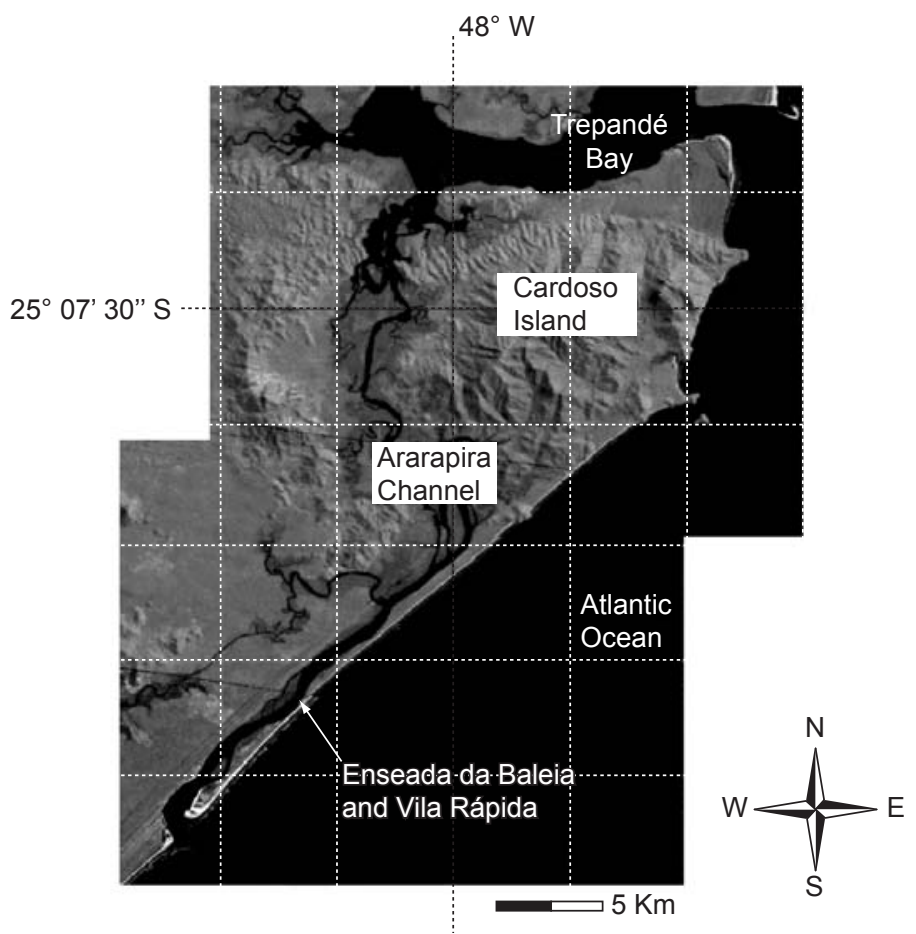

Fig. 1 - Satellite image of Cardoso Island and surroundings. (www.obt.inpe.br/prodes).

also identified by their locally used names, and were later taxonomically classified.

Analysis of the by-catch of manjuba fishery was based on samplings gathered in 7 fishing trips that occurred during our bimonthly visits. On each of these occasions, a different pair of fishermen were observed as they sorted the catch.

\section{RESULTS AND DISCUSSION}

\section{Characterization of manjuba fishery}

Manjuba fishery as practiced in the Enseada da Baleiaand Vila Rápida communities relies mainly on the filó, a fine mesh ( $2 \mathrm{~mm})$ net, approximately $50 \mathrm{~m}$ in length, and $3.5 \mathrm{~m}$ in height. In this type of fishery dug-outs are used, which are common among caiçaras.

Fishing is done along the Ararapira, the estuarine channel between Saco da Baleia (25 $16.471^{\prime} \mathrm{S}$ and $048^{\circ} 04.374^{\prime} \mathrm{W}$ ) and the now uninhabited Ararapira village $\left(25^{\circ} 13.961^{\prime} \mathrm{S}\right.$; $\left.048^{\circ} 01.491^{\prime} \mathrm{W}\right)$. Because of the height of the nets used, manjuba fishing is restricted to the channel's margins.

The fishermen frequent several channel points of the channel annually, since manjuba species present migratory behavior and use different spots along the estuary for feeding and reproduction. Sometimes the fishermen travel great distances in order to locate fish shoals, mainly when the latter enter regional rivers.

Points are fished while profitable, and then abandoned for others until meeting the quota for the day.

Smith (1983) carried out one of the most complete revisions of anthropological applications of models based on Optimal Foraging Theory (OFT), which proposes that foragers seek to consume the most energy while expending the least. Begossi (1996), in using one of the categories of analysis of this theory, which in the present case would be applied to the distance between a fisherman's residence and the fishing site, and time spent in fishing in relation to the catch, detected no marked connection between these variables, which was attributed to constant fish movement. 
In manjuba fishery, mobility is a highly significant variable since this species is migratory. Naturally, fishermen follow shoal movement along the estuary as closely as possible, unlike those who fish in fixed areas (Forman, 1967; Diegues, 1983; Maldonado, 1989; Cordell, 1989; Begossi, 1996).

Fishermen normally respect occupied fishing sites. But this courtesy was not observed among those who fish for manjuba. The result is that productive fishing spots are normally either kept secret or lied about. In small-scale fishing communities along the Brazilian coast this behavior has been observed by many researchers (Forman, 1967; Acheson, 1981; Diegues, 1983; Maldonado, 1989; Costa-Neto \& Marques, 2001).

Diegues (1983) observed this same strategy used to prevent dissemination of local accumulated environmental knowledge and to keep secret what is understood of fishery as an art. Forman (1967) described secret-keeping among fisherman as a strategy, which is used along the coast of Alagoas State, to monopolize fishing in determined areas, thus diminishing competition and preventing excessive fishing.

This strategy was found to be common in Vila Rápida as a means of excluding fishermen living in Enseada da Baleia, who have alternative income sources. According to Berkes et al. (1989), exclusion is a determinative factor in group capacity to manage resources.

However, information exchange on shoal localizations takes place among relatives that use common fish cleaning and marketing areas, According to Begossi (1995), who studied Sepetiba Bay and Búzios, Rio de Janeiro State). this collaboration is typical of many others in the caiçara culture that are kinship-based and include informal family rights in the use of fishing areas and access to other resources.

Manjuba fishery in the Enseada da Baleia and Vila Rápida communities is carried out by lanço, in which the area to be fished is delimitated (Fig. 2). After spotting fish, the fishermen surround them, while one remains on the channel margin securing a point of the net. The more experienced fishermen paddle towards the farther side of the shoal and release the net. The net, attached to the center of the dug-out canoe, is gradually cast into the water as the dugout returns to the shore. After a signal is given, the fisherman at the margin begins hauling in the net. After return of the dugout, both fishermen haul in the net, gradually narrowing the fishes' escape route.

Since the manjuba shoal can be spotted by eye, the possibility of bycatch diminishes, as it is by returning to the water fingerlings of other species as the net is being pulled in.

This procedure, which qualifies as a meme ${ }^{2}$, with immature fish, was referred to among manjuba fishermen, and was referred to by the majority of the fishermen interviewed, who represented various. The eldest among them explained the practice as a way to preserve fish stock. In the fishing trips observed by us, this practice extended to bycaught fish. Even so, $56 \%$ of the trips resulted in either no reject, or rejection of a small number (up to 28) of individuals, returned to the estuary water by previously returning fishing expeditions.

Among the fishermen studied, using the lanço resulted in only sporadic catching of other species, whose temporary location, as explained by the fishermen, happened to coincide with that of the manjuba.

Small-scale infrastructure in manjoba fishery limits the catch, of which the largest in the studied communities during a single fishing event was $180 \mathrm{~kg}$, which fit into 6 equal containers. This limit corresponds to the maximum capacity of the dugout (as attested to by a fisherman's remark: "Today we cast the net close to Barra do Ararapira and we got enough to fill 12 boxes; we had to let most of it go for lack of space in the dugout") and to the supply of material (mesh and canvas matting) to dry fish for marketing. If a satisfactory amount is reached (up to 6 boxes) during a haul, the fisherman goes back to the village, usually for the remainder of the day. Catching, transporting, and drying the fish for marketing follow one another in quick succession and require heavy investments of time and energy.

\section{Social context}

\section{History of the regional manjuba fishery}

Manjuba fishery began in the Enseada da Baleia and Vila Rápida communities with the arrival of the first Japanese families in Registro, São Paulo

\footnotetext{
2 "Meme" is a term coined by Dawkins (1989) and refers to a unit of cultural information traveling from brain to brain through what is essentially a process of imitation. It is used to characterize a fragment of cultural inheritance.
} 

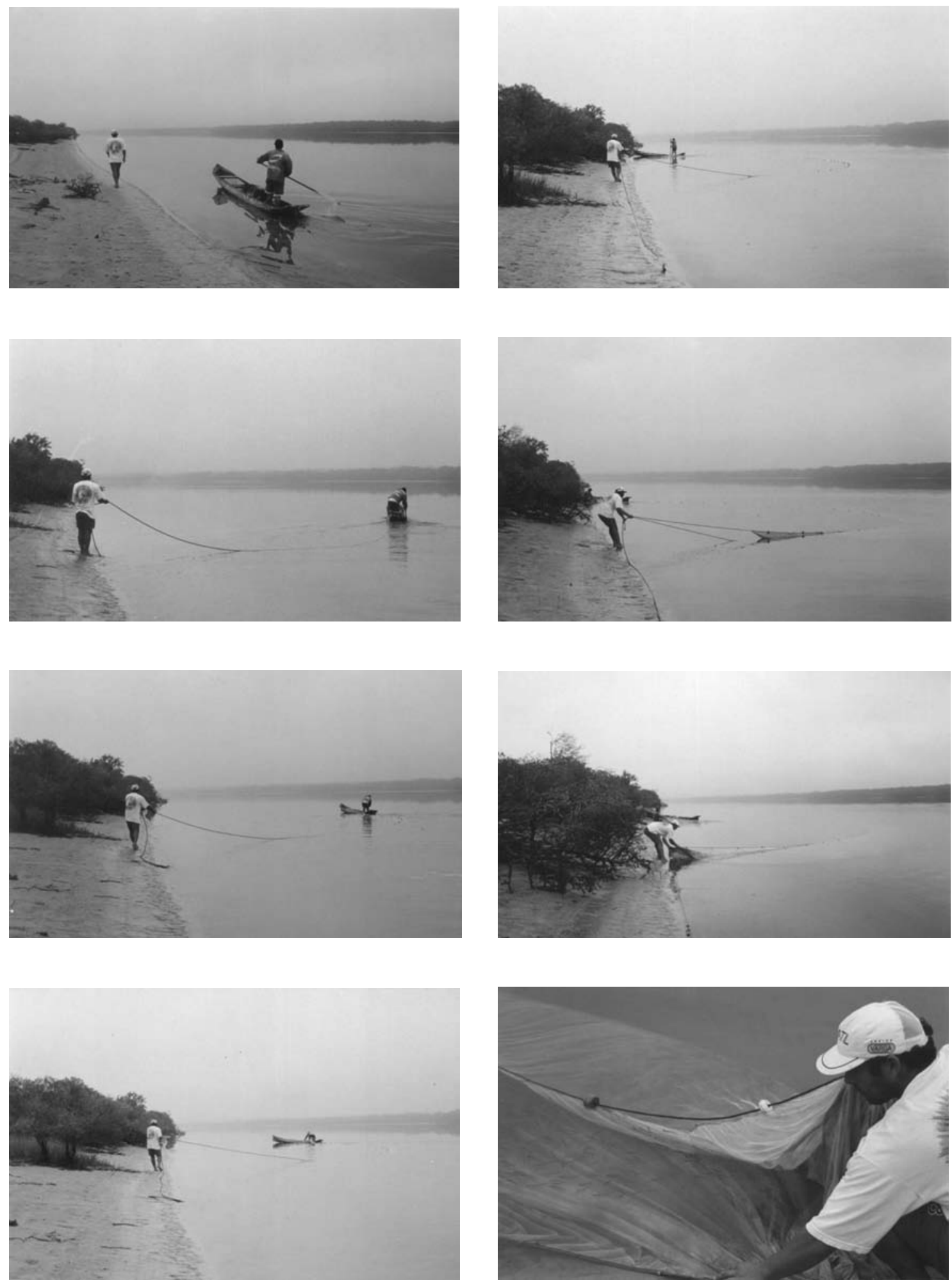

Fig. 2 - "Lanço": technique used in manjuba fishing. 
State, in 1913, who introduced manjuba fishing and marketing. Mussolini (1980) cited Japanese immigration as an important influence on caiçara culture, particularly because of having introduced these fishery innovations. However, this was not the most frequent fishing activity in the area.

Among caiçaras, other fishing techniques were more common, e.g., permanently fixed nets (cerco fixo), as well as other net types used in the estuary.

About 45 years ago a group of Japonese residing in Registro joined a family member living on Cardoso Island and constructed, in the area that is now Enseada da Baleia, a type of bunkhouse for drying sardines and manjuba, thus upgrading the market value of manjuba. However, this induced no change in small-scale manjuba fishery nor in the fine-mesh nets of limited capacity traditionally used.

Industrial-scale sardine fishing along the coast contributed to a significant decrease in estuary sardine stock, thus in production, and ultimately ended the drying facility operation. According to Dias-Neto \& Marrul-Filho (2003), the sardine catch peaked in 1973 , followed by a marked decline in subsequent years as the fishery fleet grew. But smaller-scale manjuba fishery continued, with manjuba and other species caught being sold to local merchants.

Currently, even this process is undergoing change as a result of the gradual reduction of fishing stock, caused by industrial coastal fishing, as well as of reductions in market value, both of which generate conflict between small-scale fishermen and industrial fishing interests. With their source of an ever more meager livelihood being increasingly threatened, village fishermen turned again to manjuba, which has a greater market value than other species regionally fished. In studying Paraná coastal fishing, Andriguetto-Filho (1999) found that small-scale fishing depends on pristine environments. He shows that diminished catches, changes in species caught, and environmental degradation, have stimulated fishing-gear changes and other innovations in small-scale fishery, including that of fisherman of Enseada da Baleia and Vila Rápida.

Two peaks in manjuba fishery occurred in the communities studied, as shown by an analysis of time spent in fishing. Among presently active fishermen, $50 \%$ began following the installation of the drying facility, The remainder joined their ranks within the past ten years, gradually increasing the working force in the estuary as this type of fishery grew as an alternative in relation to other types of fishery in that same area.

As overexploitation of fish stock intensified, manjuba fishery expanded. The first occurred as a result of the implementation of a developmental model, intended only for industrial fishing and focused exclusively on production, created by the Supervisory Commission for Fishery Development (SUDEPE) with no regard for environmental impact. To exacerbate the situation, environmental legislation regulating industrial fishery zoning limits is neither respected nor enforced. Frequently, industrial-fleet fishing vessels appear within close range of Cardoso Island beaches.

\section{Manjuba-fishing and social organization}

Strong bonds of kinship, acharacteristictypical of small, relatively isolated fishing communities, were found among the village inhabitants studied. Mello (1995) holds that kinship is the basis of all social relations in traditional societies. Fishing partnerships, generally of brothers or brothers-inlaw and commonly including children as helpers or apprentices, form within these families, thus increasing family income and preserving traditional fishing methods. Maldonado (1986) sees this production mode as crucial as it promotes flexibility in distributing and marketing fish catches.

The division of the catch depends on fishing gear ownership and participation in the work, and is carried out by separating the haul into three parts, of which the owner of the gear receives two, and his partner, the third. Diegues (1983) describes this procedure as typical of those carried out in smallscale fishery.

Community organization is patriarchal, with men being charged with family support, and the women, with the household work as well as occasionally preparing fish for marketing. (In the Cardoso Island region, only one woman was observed participating in manjuba fishery.) According to Acheson (1981), such work division is common among most of the world's fishing cultures.

Most fishermen (75\%) from the two communities studied cited manjuba fishing as important 
for family sustenance. But in Enseada da Baleia, it now includes only four fishermen, is secondary in economic importance, is resorted to exclusively in the absence of other income sources, and limited to the use of cerco fixo, which consists of marking an area to catch tainha (Mugil sp.).

Within the past two years tourism began to develop in Enseada da Baleia, in which basic infrastructure had already existed, and which has become a source of income for the population.

However, in Vila Rápida manjuba fishing remains the community's main economic activity. At this point, two of the village families maintain houses, cared for by two villagers, for tourist rentals. As an additional source of income, residents accept tourists wishing to set up tents on their properties.

\section{Patrolling fishery}

Patrolling of manjuba fishery was identified by Enseada da Baleia and Vila Rápida fishermen as an obstacle to the exercise of their occupation. Although no reports exist among the fishermen on fishing-gear seizures, license revocations, or violator apprehensions, the legal status of their fishery is uncertain to local fishermen, who are unfamiliar with relevant legislation.

Manjuba fishing hours and places are planned so as not to coincide with those thought likely for the control agents. Normally fishing occurs early in the day, before the agents are on duty, but when neap tides coincide with patrolling, fishing in more distant spots becomes hazardous as the risks of being caught are greater. Fishing regulation also determines locations available. Although most of them prefer Trapandé Bay, which is located near Cananéia, and heavily stocked with manjuba, none fish near the town, even those with motor-powered boats, so to avoid patrollers.

In addition, fishermen associate having a fishing license to being policed more closely and to their manjuba fishery technique, and only $38 \%$ of the manjuba fishermen are licensed. But the general perception prevailing among the fishermen in the community is that they are unable to protect their collective interests.

Historically, legislation has always been more heavily enforced among small-scale fisheries, rather than large-scale industrial fisheries and their owners. Although small-scale manjuba fishery is suspected of being predatory, until now this has not been proven (Andriguetto-Filho, 1999). Therefore, as is true for the greater part of Brazilian fishery regulation, prohibiting fishing for manjuba was not based on ecological data and totally ignores the social consequences of regulatory enforcement.

\section{Ecological context}

\section{Ethnoecological knowledge}

Marques (1991) affirmed that successful fishermen depend on their accumulated knowledge of fish ecology and behavior. In the case of the fishermen studied, this knowledge in part is the byproduct of searching out manjuba shoals in the estuarine channel. For example, these fishermen can identify by sight manjuba species by their behavior in the estuary. Thus, that of the manjubachata (Anchoa marinii) is comparatively mild, making it easier to catch, while manjuba-branca (Anchoa tricolor) is aggressive, and usually found farther out in the channel.

In general, the fishermen know the areas where manjuba species stocks occur in determined periods, and are familiar with their habitats and migratory routes.

It is also known that the manjubas-branca (Anchoa tricolor), and pregão (Anchoa lyolepsis), which prefer clean salt water, reproduce and develop mostly in the open sea, and only enter the channel occasionally. Pessanha \& Araújo (2003) described similar characteristics in the Anchoa tricolor in Sepetiba Bay (RJ, Brazil). In the present work, a high frequency of juveniles of this species was observed in the outer part of the Trepandé Bay, indicated by the fishermen as the recruiting point. In interviews, they also associated Anchoa tricolor with the following environmental factors of waters fished: high transparency, and low salinity and temperatures. According to the fishermen studied, manjuba-chata (Anchoa marinii) prefers estuarine environments, in which it spends the greater part of its life span. This species comes from the sea to the Trepandé Bay where, according to the fishermen, it spawns, returning immediately to the estuarine channel and from there to the sea. However, this information has not yet been scientifically established. According to Silva \& Araújo (1999), in the Sepetiba Bay salinity was probably the major environmental factor determining location of the most abundant species of Engraulidae, RJ, which 
must have undergone an adaptive process to avoid competition in resource expoitation.

The data obtained on the two most frequently caught species (Anchoa marinii e Anchoa tricolor) in Sepetiba Bay agree with information on differentiated habitats supplied by the fishermen studied.

These fishermen also pointed out considerable annual variation in abundance of manjuba species in the estuary, a fluctuation which in Engraulidae is related primarily to environmental factors that influence recruitment (Villamor, 2002). From the egg stage through recruitment, rates of mortality are high and vary in accordance with even slight environmental differences, such as food availability or predator numbers (Irazola et al., 1996). These same authors point out that recruitment and, thus, the future of fishery itself is even more dependent on environmental conditions than it is on numbers of sexually mature fish.

According to the fishermen, manjuba-chata always constitute the major part of the catch, due to habits and behavior that facilitate capture. In addition they revealed that catch of this species during 2002 exceeded the average of the previous several years. One of the local manjuba buyers explained this increase by the overexploitation of manjuba predators by offshore industrial fleets. Tamura (2002) drew attention to consequences of predator population fluctuations being both important and ignored in open-sea fishery. He adds that the removal of predators can result in their being substituted by others occupying the same position in the trofic chain, which culminates in production increase at lower levels of the trofic chain and long-term changes in the ecosystem.

The fishermen had noted the annual variation of iriko, which is the larval stage of Anchoa sp., and which according to them is jeopardized by insufficient rain during the summer, which in turn limits recruitment results.

The fishermen also were highly aware of abiotic factors relevant to fishing, i.e., rain, wind, tides, and solar incidence. Of these, the tides were singled out as being of particular importance, because they regulate manjuba fishing periods. Neap tides, which are relatively calm, are good for manjuba fishing, but the interval between ebb and the flood yields the best catches. Cordell (1978), Nordi (1994), Mourão et al. (1996), and Nishida
(2000) also observed that the tidal cycles determine fishing strategies used in subsistance fishing.

Rain is also regarded by the fishermen are strongly related to manjuba in the estuary. The absence of rain in the basin's area hinders the manjubas' return to the sea from the rivers of the area's basin. On the other hand, excess rain prohibits use of the primitive drying method used.

Wind was also indicated as an important factor in manjuba fishery. According to the fishermen, southeasterly winds are best, because they facilitate manjuba entrance into the estuarine channel from the sea.

\section{Economic context}

Manjuba fishery has a limited market, mainly constituted by Japanese restaurants and markets, which partially determine fishery levels. When manjuba catches are generous, the point of diminishing returns eventually sets in, following which prices fall abruptly. In the ensuing months, manjuba fishery virtually ceases. As one fisherman said, "There were days when you looked out at the sea and the fish were as plentiful as raindrops. But for lack of buyers nobody fished; out there, the water was saturated with fish and no one would buy it at any price."

The studied fishermen are concerned about the currently high supply of manjuba and the increasing numbers of individuals involved in this type of fishery, mainly in the communities surrounding the same drainage channels in which they fish. They fear exponential growth in the number of manjuba fishing nets and the market saturation that it may mean.

Moreover, the lack of an motor-powered boat in Vila Rápida makes these fishermen dependent on hiring someone to deliver the catch to the market. Furthermore, this person also stipulates the price paid for the catch, upon whom the fishermen are completely dependent.

Two types of trading were observed in the two villages studied. One is initiated by the merchant, in this specific case a former manjuba fisherman of Enseada da Baleia, who then resells to another middleman in Cananéia, who in turn markets the fish to other buyers.

The other type begins with middlemen who deal directly with the Vila Rápida fishermen and sell to retailers in São Paulo, SP. 
The fish are sold at previously agreed prices, which is generally low compared to the final market value. But it has the advantage of reducing risks when the market is saturated (Acheson, 1981). Nordi (1992) also observed this system among crabmen in Paraíba State, which functions regardless of market fluctuation, and guarantees some profit.

In the case of the communities studies, the local merchant owns the only market and often barters with the villagers. Other middlemen, who buy netting wholesale and sell or barter it to the fishermen in exchange for fish, usually supply the nets. However, dependency on the middleman reduces the negotiating power of the fishermen, which is further undermined by competing to sell their hauls. The fish is marketed only when dried. The ratio between fresh and dry weights is approximately $6 \mathrm{~kg} / 1 \mathrm{~kg}$. Manjuba commercial value is inversely proportional to their size, so that iriko is more profitable than mature manjuba, whose annual market value varied according to supply. However, iriko is available only for only a few weeks in summer.

\section{Features of manjuba fishing co-management}

In the economic life of Enseada da Baleia and Vila Rápida the market is the preponderant factor. The fact that these communities and those of the surrounding villages deliver their hauls to markets in the same way, added to varying market conditions, limits manjuba fishery as a source of subsistence.

When manjuba fishery was a seasonal income source, replaced in turn by other seasonally available species, these variations presented no threat to community livelihood. But with coastal environmental changes, added to falling fish prices, which decreased the economic viability of other types of fishery in the estuary, manjuba fishery attracted more fishermen. Market oversupply resulted and community income declined.

The crisis now looming in small-scale fishing in the two communities studied can only be resolved at its real root, which is local industrial fishing. If its impact is to be diminished and fish stocks are to return to the estuary, control is an urgent matter A project now under discussion proposes the creation of a southern coastal extractive reserve to protect natural resources and from which industrial fishery would be banned. This would be controlled by local community populations that would bear responsibility for preserving the many aspects of caiçara culture. This project falls within the purview of the Co-Management Plan for Use of Fishing Resources in the CananéiaIguape-Ilha Comprida and Adjacent Coastal Area Estuarine-Lagoonal Complex (IBAMA, 2003). Begossi \& Brown (2003) call attention to Latin American examples of regulated co-management created to minimize conflict between small-scale and industrial fisheries: Management of Exploited Coastal Areas (Chile), Tamishiyacu-Tahuayo Communal Reserve (Peru), and the Sustainable Development Reserve (Mamirauá, (Brazil).

Effective patrolling of industrial fleets will have to replace currently weak coastal surveillance, and heavy fines must be imposed on their owners, who are largely responsible for fish stock depletion, instead of individual fishermen, who pay a price for violating legislation and who are easy enforcement targets. In addition, incentives must be given to small-scale fisheries. In addition, fishery cooperatives should be encouraged, community local organizations fortified, and middlemen eliminated. Maldonado (1986) emphasizes that in the government-sponsored creation of cooperatives, any innovations must be in response to the real needs and objectives of the fishermen themselves.

As a result of the present analysis, in which substantial accumulated environmental knowledge related to manjuba fishery was discovered among the fishermen, and in view of the environmentallyfriendly fishing gear used, we propose freeing manduba fishery in a permanently monitored area for Cardoso Island communities under the authority of the present Cardoso Island CoManagement Committee, an already established group. Registering and tagging of nets, a part of the proposal would limit their number, which would be fixed, with the committee controlling purchase of new ones. Environmental control of local fishery would be done through constant maintenance of fishing catch records, upon which sustainable exploitation plans for stocks would be based.

Finally, fishery biology analysis cannot be detached from fishing itself, nor from the context in which it occurs. This is also true for resource management decisions and the fishermen they affect. In this connection, a manjuba fishery- 
zoning proposition, suggested by a former fisherman, would allow unrestricting fishing in delimited areas, and seems feasible regionally. This fisherman describes affirms that Trepandé Bay has large manjuba shoals and is a reproduction site. The proposal intends to transform Trepandé Bay and the estuarine channel up to the Varadouro Channel, areas previously fished and currently offlimits to fishermen, into a sanctuary for maintaining manjuba stock.

We stress the importance of creating ecologically sound and socially constructive alternatives in natural resource use and management. This can be done through integrating knowledge and through dialogue among researchers, public agencies, and affected communities.

Acknowledgments - We thank Dr. Naércio Menezes of the Zoology Museum of the University of São Paulo (MZ/USP) for taxonomical classification of manjuba, the team from the Laboratory of Human Ecology and Ethnoecology of the Federal University of São Carlos, (LEHE//UFSCar) for aid in fieldwork, and the fishermen of Cardoso Island for their good will and openness.

\section{REFERENCES}

ACHESON, J. M., 1981, Anthropology of fishing. Ann. Rev. Anthropol, 10: 275-316.

ANDRIGUETTO-FILHO, J. M., 1999, Sistemas Técnicos de Pesca e suas Dinâmicas de Transformação no Litoral do Paraná, Brasil. Tese de doutorado - Universidade Federal do Paraná, Université Paris 7, Université Bourdeaux 2.

BEGOSSI, A., 1995, Fishing spots and sea tenure: incipient forms of local management in Atlantic Forest coastal communities. Human Ecology, 23: 387-406.

BEGOSSI, A., 1996, Fishing Activities and Strategies at Búzios Island (Brazil). In: R. M. Meyer, C. Zhang, M. L., Windsor, B. J., McCay, L. J., Hushak, and R. M. Muth (eds.), Fisheries Resource Utilization and Policy. Proceedings of the World Fisheries Congress Theme 2, Oxford \& IBH Publishing CO. PVT. LTD, Calcutta.

BEGOSSI, A. \& BROWN, D., 2003, Experiences with fisheries co-management in Latin American and the Caribbean. In: D. C. Wilson; J. R. Nielsen and P. Degnbol (eds.), The Fisheries Co-Management Experience. Accomplishment, Challenges and Prospects, Kluwer Academic Publishers. Fish and Fisheries Series 26, Dordrecht, Boston, London.

BERKES, F., FEENY, D., McCAY, B. J., \& ACHESON, J. M., 1989, The benefits of the commons. Nature, 340: 91-103.

CHIZZOTI, A., 2000, Pesquisa em Ciências Humanas e Sociais. Cortez Editora.

CORDELL, J., 1978, Swamp dwellers of Bahia. Natural History, Jun. 1978: 62-74.

CORDELL, J., 1989, Social Marginality and Sea Tenure in Bahia. In: A Sea of Small Boats. Cultural Survival, Inc.
COSTA-NETO, E. M. \& MARQUES, J. G. W., 2001, Atividades de Pesca Desenvolvidas por Pescadores da Comunidade de Siribinha, Município de Conde, Bahia: uma Abordagem Etnoecológica. Sitientibus série Ciências Biológicas, 1(1): 71-78.

DAWKINS, R., 1989, O gene egoísta. Ed. Gradiva, Lisboa.

DIAS-NETO, J. \& MARRUL-FILHO, S., 2003, Síntese da Situação da Pesca Extrativa Marinha no Brasil. Documento elaborado para a apresentação aos integrantes do grupo de trabalho interministerial-GTI criado com a finalidade de definir Programa de Financiamento da Frota para Pesca Oceânica e de Renovação e Modernização da Frota Costeira - Decreto s/n, de 13 de junho de 2003. IBAMA/ DIFAP/CGREP, Brasília.

DIEGUES, A. C. S., 1983, Pescadores, Camponeses e Trabalhadores do Mar. Editora Ática, São Paulo.

DIEGUES, A. C. S., 1988, Diversidade biológica e culturas tradicionais litorâneas: o caso das comunidades caiçaras. NUPAUB/CEMAR-USP, série documentos e relatórios de pesquisa n. 5, São Paulo.

DIEGUES, A. C. S., 2001, Ecologia Humana e Planejamento Costeiro. Hucitec NUPAUB-USP, $2^{\mathrm{a}}$ edição, São Paulo, 290p.

ÉSPER, M. L. P., 1980, Aspectos Biológicos da Anchoa januaria (Steindachner, 1879) na Região de Ponta da CruzBaia de Paranaguá-Paraná, Brasil. Tese de doutorado Universidade Federal do Paraná, Curitiba.

FIGUEIREDO, J. L. \& MENEZES, N. A., 1978, Manual de peixes marinhos do sudeste do Brasil. Teleostei. Museu de Zoologia de São Paulo, Universidade de São Paulo.

FORMAN, S., 1967, Cognition of the catch: the location of fishing spots in a Brazilian coastal village. Ethnology, 6: 417-26.

IBAMA, 2003, Plano de Gestão Participativa para o Uso dos Recursos Pesqueiros do Complexo Estuarino-Lagunar de Cananéia-Iguape-Ilha Comprida érea CosteiraAdjacente. IBAMA/APA Cananéia-Iguape-Peruibe. Iguape, SP.

IRAZOLA, LUCCHETTI, LLEONART, OCAÑA, TAPIA \& TUDELA, 1996, La pesca en el Siglo XXI: propuestas para una gestión pesquera racional em Catalunya. CCOOCEPROM-FORCEM, site: www.icm.csic.es.

MALDONADO, S. C., 1986, Pescadores do mar. Editora Ática/ Série Princípios, São Paulo, SP.

MALDONADO, S. C., 1989, O caminho das pedras: percepção e utilização do espaço na pesca simples. In: A. C. Diegues (ed.), Pesca Artesanal: Tradição e Modernidade, III Encontro de Ciências Sociais e o Mar: Coletânea de Trabalhos Apresentados, Programa de Pesquisa e Conservação de Áreas Úmidas no Brasil, São Paulo.

MARQUES, J. G. W., 1991, Aspectos ecológicos na etnoecologia dos pescadores do complexo estuarino-lagunar de MundaúManguaba, Alagoas. Tese de Doutorado - Universidade Estadual de Campinas, Campinas, SP, 285p.

MARQUES, J. G. W., 1995, Pescando Pescadores. Etnoecologia abrangente no baixo São Francisco alagoano. NUPAUB/ USP, São Paulo, 285p.

MELO, P. R. N., 1996, Composição específica e estrutura em tamanho das capturas de Engraulidideos na Baia de 
Paranaguá, Paraná, Brasil. Monografia apresentada na Pontifícia Universidade Católica do Paraná, Curitiba.

MELLO, L. G., 1995, Antropología cultural. Editora Vozes, $6^{\circ}$ edição, Petrópolis, RJ.

MOURÃO, F. A. A., 1971, Os pescadores do litoral sul do estado de São Paulo: um estudo de sociologia diferencial. Tese de doutorado - FFLCCH-USP, São Paulo.

MOURÃO, J. S., NISHIDA, A. K,. \& NORDI, N., 1996, Estratégias na pesca de subsistência influenciadas por movimentos de maré e fases da lua. Congresso de Ecologia do Brasil. 3: 246.

MUSSOLINI, G., 1980, Ensaios de Antropologia Indígena e Caiçara. Editora Paz e Terra, RJ.

NISHIDA, A. K., 2000, Catadores de Moluscos do Litoral Paraibano: Estratégias de Subsistência e Algumas Formas de Manejo. Tese de doutorado - Universidade Federal de São Carlos, São Carlos.

NORDI, N., 1992, Os catadores de caranguejo-uçá (Ucides cordatus) da região de Várzea Nova (PB): uma abordagem ecológica e social. Tese de doutorado - Universidade Federal de São Carlos.

NORDI, N., 1994, A captura do caranguejo-uça (Ucides cordatus) durante o período reprodutivo da espécie: o ponto de vista dos caranguejeiros. Revista Nordestina de Biologia 9(1): 41-47.

PESSANHA, A. L. M. \& ARAÚJO, F. G., 2003, Spatial, temporal and diel variations of fish assemblages at two sandy beaches in the Sepetiba Bay, Rio de Janeiro, Brazil. Estuarine Coastal and Shelf Science, 57(2003): 817-828.

PINHEIRO, P. C., CORRÊA, M. F. M., SPACH, H. L., 1994, Caracteres Consistentes para Identificação de Pós-larvas, Juvenis e Adultos de Anchoa parva e Anchoa tricolor (PISCES, ENGRAULIDAE). Arq. Biol. Tecnol., 37(4): 843-852.
SALES, R. J. R., 1988, Aspectos da pesca artesanal na região lagunar de Iguape-Cananéia. In: Ciências Sociais e o Marno Brasil, II Encontro. Coletânea de Trabalhos Apresentados. Programa de Pesquisa e Conservação de Áreas Úmidas no Brasil, São Paulo.

Secretaria de Estado do Meio Ambiente (2001) Plano de Manejo do Parque Estadual da Ilha do Cardoso (PEIC, SP - Deliberação CONSEMA, n. 30, 2001.

SEIXAS, C. S. \& BERKES, F., 2003, Dynamics of socialecological changes in a lagoon fishery in southern Brazil. pp. 271-298. In: F. Berkes, J. Colding \& C. Folke. Navigating social-ecological systems: building resilience for complexity and change.

SILVA, M. A. \& ARAUJO, F. G., 1999, Influência dos fatores ambientais na estrutura de populações de manjubas (Clupeiformes-Engraulidae) na Baia de Sepetiba, Rio de Janeiro, Brasil. Acta Biol. Leopoldensia, 21: 229-240.

SMITH, E. A., 1983, Anthropological Applications of Optimal Foraging Theory: A Critical Review. Current Anthropology, 24(5): 625-651.

TAMURA, T., 2002, Competición por los alimentos en el océano: el hombre y otros predadores apicales. Conferencia de Reykjavik sobre la pesca responsable en el ecosistema marino. site: www.ieo.es.

TOLEDO, V. M., 1992, What is Ethnoecology? Origens, Scope and Implications of a Rising Discipline. Etnoecológica, 1(1): 5-21.

VIERTLER, R. B., 2002, Métodos Antropológicos como ferramenta para estudos em Etnobiologia e Etnoecologia. In: M. C. M. Amorozo, L. C. Ming (eds.) Métodos de coleta e Análise de dados em Etnobiologia, Etnoecologia e disciplinas correlatas, Silva. Anais do I Seminário de Etnobiologia e Etnoecologia do Sudeste, Rio Claro, 204p.

VILLAMOR B., 2002, Biologia y Dinâmica de lãs Poblaciones de Anchoa y Sardina en el área del ICES (BIODAS). Hoja informativa - Instituto Español de Oceanografía. n. 65. site: www.ieo.es. 
